\title{
Institutional strategies to prevent violence in nursing work: an integrative review
}

\author{
Estratégias institucionais de prevenção à violência no trabalho da enfermagem: revisão integrativa
}

Estrategias institucionales de prevención contra la violencia laboral en enfermería: una revisión integrativa

Cícera Adriana Rodrigues Pereira'

ORCID: 0000-0002-9556-5033

Maria Helena Borgato"

ORCID: 0000-0002-8702-8123

Rosana Maria Barreto Colichi"

ORCID: 0000-0002-8765-3965

Silvia Cristina Mangini Bocchi"

ORCID: 0000-0002-2188-009X

' Secretaria Estadual de Saúde, Hospital das Clínicas de Botucatu. Botucatu, São Paulo, Brazil.

"Universidade Estadual Paulista, Faculdade de Medicina de Botucatu. Botucatu, São Paulo, Brazil.

How to cite this article:

Pereira CAR, Borgato MH, Colichi RMB, Bocchi SCM. Institutional strategies to prevent violence in nursing work: an integrative review. Rev Bras Enferm. 2019;72(4):1052-60. doi: http://dx.doi.org/10.1590/0034-7167-2018-0687

Corresponding Author:

Silvia Cristina Mangini Bocchi

E-mail: silvia.bocchi@unesp.br

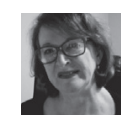

Submission: 08-20-2018 Approval: 10-25-2018

\begin{abstract}
Objective: To analyze the production of research that adopted as object of investigation: institutional strategies, actions and programs to curb and/or prevent the nursing workplace violence. Method: Integrative review of 14 articles in full, available in the databases LILACS, PubMed Central, Scopus, CINAHL and Web of Science. Results: Of the articles analyzed, most arise from quantitative research (71\%), carried out in the United States (65\%), with educational actions (57\%) and programs (43\%), denoting policies. Conclusion: Results showed various ways to curb or prevent nursing workplace violence. These are specific strategies, there are few programs deployed worldwide, usually centered in the United States, Canada and Sweden. Most of them is well evaluated and can serve as a model for the development and dissemination of policies according to the needs of each location. Descriptors: Occupational Health; Violence; Work; Nursing; Programs.
\end{abstract}

\section{RESUMO}

Objetivo: Analisar a produção de pesquisas que adotaram como objeto de investigação: estratégias institucionais, ações ou programas/políticas para coibir e/ou prevenir a violência no trabalho da enfermagem. Método: Revisão integrativa de 14 artigos na íntegra, disponíveis nas bases de dados LILACS, PubMed Central, Scopus, CINAHL e Web of Science. Resultados: Dos artigos avaliados, a maioria é oriunda de pesquisas quantitativas (71\%), realizadas nos Estados Unidos (65\%), com ações educacionais (57\%) e programas (43\%), que denotam políticas. Conclusão: Os resultados demonstraram diversas formas de coibir ou prevenir a violência no ambiente de trabalho da enfermagem. São estratégias pontuais, há poucos programas implantados mundialmente, centrados nos Estados Unidos, Canadá e Suécia. A maioria deles é bem avaliada e pode servir como modelo para o desenvolvimento e propagação de políticas, conforme as necessidades de cada local. Descritores: Saúde do Trabalhador; Violência; Trabalho; Enfermagem; Programas.

\section{RESUMEN}

Objetivo: Analizar la producción de investigaciones que adoptaron como objeto de investigación: estrategias institucionales, acciones o programas/políticas para inhibir y/o prevenir la violencia laboral en enfermería. Método: Revisión integrativa con 14 artículos por completo disponibles en las bases de datos LILACS, PubMed Central, Scopus, CINAHL y Web of Science. Resultados: De los artículos evaluados, la mayoría proviene de encuestas cuantitativas (71\%), realizadas en Estados Unidos (65\%), con acciones educativas (57\%) y programas (43\%), que apuntan a políticas. Conclusión: Los resultados apuntan diversas formas de inhibir o prevenir la violencia laboral en enfermería. Las estrategias son aisladas, hay pocos programas implantados en el mundo y estos se encuentran centralizados en Estados Unidos, Canadá y Suecia. La mayoría de ellos son muy bien evaluados y pueden servir como modelo para desarrollar y promover políticas, según las necesidades de cada lugar. Descriptores: Salud Laboral; Violencia; Trabajo; Enfermería; Programas. 


\section{INTRODUCTION}

Violence in the nursing work is not only a problem of worker's health but also a public health issue in global scenarios, according to studies conducted in North American countries and in the African, European and Asian continents ${ }^{(1-11)}$.

According to the World Health Organization (WHO), violence is the intentional use of physical force or power, threatened or actual, against oneself, another person or a group, and can result in injury, death, psychological harm, maldevelopment or deprivation, with consequent reduction in revenue, leading to immediate or late consequences ${ }^{(12)}$. WHO, in partnership with the International Labour Organization (ILO), defined occupational violence as that in which abuses, threats or attacks to individuals occur in their job occupations or even during their commute, and that may risk the safety, welfare or health of individuals ${ }^{(13)}$.

In the health sector, the effects of violence can be evidenced by the increased morbidity and mortality over the last 30 years, caused by interpersonal assaults, racial and class discrimination, abuses and dominations. They may occur in interpersonal or institutional levels, in the micro or macropolitical-social environment, resulting from a dynamic process of society, fed by individual interests occasioned by behavioral changes of individuals and health services ${ }^{(13)}$.

Recognition of occupational violence as one of the major public health problems can be considered recent in Brazil. The milestone came in the 1990s when this type of violence started to be considered as that one occurring in the workplace. Classified as structural or institutional and behavioral or relational, it can cause damage both to the worker as to those under their care, as it leads to a decline in their health standard and quality of the service provided ${ }^{(14)}$.

In the exercise of their everyday functions, health professionals still suffer subtly with various kinds of violence, both physical and emotional, involving threats or physical abuse, emotional and sexual harassment, from both internal (supervisors, colleagues) as external (visitors, family or not) offenders ${ }^{(13)}$.

Psychological violence includes actions or omissions that cause or aim to cause damages to self-esteem, identity or personal development ${ }^{(15)}$, and its main elements are: bullying, sexual harassment, racial discrimination, intimidation, threats and hostilities. Such acts can lead the individual to psychological disorders such as anxiety and depression ${ }^{(16)}$ and may incur in suicide ${ }^{(15)}$, in addition to being the cause for $18 \%$ of work-related health problems, representing on average two or more weeks of absence ${ }^{(15,17)}$.

External violence is committed by individuals who do not belong to the organization, i.e., a stranger. This usually reflects the violence of the streets and the greatest victims are nursing professionals whose workplaces are geographically located in areas with high rates of violence. Internal violence, in turn, occurs among the workers of the institution themselves, due to hierarchy - bullying -, or in horizontal interpersonal relations ${ }^{(16)}$.

In Brazil, it is estimated the prevalence of health work violence, specifically in hospitals, is between $25.9 \%{ }^{(18)}$ and $63.2 \%{ }^{(19)}$, being verbal aggression the most common and women the greatest victims; vulnerability increases by $80 \%$ in the age group from 25 to 39 years old when compared to older people ${ }^{(18)}$.

The Federal Council of Nursing (Cofen) accounts for more than 2 million professionals, between assistants (21\%), technicians
$(55 \%)$ and nurses $(24 \%)^{(20)}$. However, the only Brazilian study about violence in nursing work nationwide pointed out that $23.9 \%$ of nurses and $18.5 \%$ of nursing technicians and assistants suffered some type of violence, being the first the psychological $(65.2 \%$; $67 \%)$, followed by physical $(10.6 \% ; 17.5 \%)$ and sexual violence $(0.6 \% ; 1 \%)^{(21)}$; similar to what occurs worldwide, regardless of the countries being developed or not, according to data set out in the discussion of this article.

To think of ways to curb the causes of nursing workplace violence, a task force of multidimensional mobilization in partnership with workers, managers, users and class bodies, in local, national and global scopes is required, one that is instrumentalized by programs/policies that, adapted to each reality, can confer better work conditions and valuation of social capital of nursing professionals in each health institution.

Therefore, this study aims to analyze the production of research that adopted as object of investigation the institutional strategies, actions and programs to curb and/or prevent the nursing workplace violence.

To carry out this research, one considers program all actions and interventions planned jointly, characterized by the systemic and global vision of activities to be undertaken in an articulated manner, so that specific objectives of each actions are concatenated and in line with the policy of prevention of workplace violence.

\section{OBJECTIVE}

To analyze the production of research that adopted as object of investigation the institutional strategies, actions and programs to curb and/or prevent the nursing workplace violence.

\section{METHODS}

Integrative review ${ }^{(22-23)}$, with the guiding question: What are and how are characterized worldwide the actions and programs/ policies employed to deter/prevent nursing workplace violence?

Sample selection was conducted through access to the databases: Latin American and Caribbean Center on Health Sciences Information (LILACS), US National Library of Medicine (PubMed Central), Scopus, Current Nursing and Allied Health Literature (Cl$\mathrm{NAHL}$ ), and Web of Science (WoS). The strategy used was a search of controlled descriptors combined with Boolean operators in the Medical Subject Headings (MeSH): "workplace violence OR bullying AND nursing AND prevention program", in the databases: Scopus, PubMed, CINAHL and WoS, without determining a specific field to search (article title; abstract; keywords etc.) but opting for all fields. The following combination was used in LILACS, according to the Health Sciences Descriptors (DeCS): "workplace violence OR prevention programs AND nursing". As inclusion criteria, one adopted the inclusion of full articles, with abstracts available and related to the research object, in Portuguese, English and Spanish, indexed in the databases referred to, from January $1 \mathrm{st}$ 2013 to December 31st 2017. Were excluded articles from reviews and those that were not available in full in the databases, in the Portal of Journals of the Coordination of Higher Education and Graduate Training (Capes). Articles repeated between bases were considered only once. 
After the corpus of analysis was configured, as shown in Figure 1, the articles were read in full, filling the instrument with the following information: article, year and journal, type of study, sample, objectives, country and location where the study was conducted and main results.

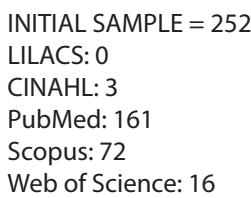

Articles excluded for failing to meet the criteria for inclusion: 221

Articles excluded for being repeated: 16
FINAL SAMPLE $=14$

CINAHL: 3

PubMed: 2

Scopus: 8

Web of Science: 1
It should be noted the research were classified according to the levels of evidence proposed by Melnyk and Fineout-Overholt ${ }^{(24)}$.

\section{RESULTS}

The 14 articles assessed, all in English, were selected due to dealing with isolated educational actions ( $8 ; 57 \%)$ and programs/ policies $(6 ; 43 \%)$ of prevention of nursing workplace violence. Most came from quantitative research (10; 71\%) with quasi-experimental designs and, thus, a level of evidence of $5(7 ; 50 \%)$, conducted in countries in the Americas - specifically North America (10; 72\%): United States $(9 ; 65 \%)$ and Canada $(1 ; 7 \%)$, followed by three (21\%) distributed equally among countries in Asia (Jordan; 7\%), Europe (Sweden; 7\%) and Oceania (New Zealand; 7\%).

Of the total, four (29\%) had nurses as study participants; two (14\%) included the nursing team; six (43\%) dealt with health workers, and two (14\%) were theoretical research, with programs proposed by experts. It is emphasized that in research whose participants were health workers, nurses and other members of the nursing team were involved.

Interventions used in the studies were carried out in hospital or outpatient health scenarios $(6 ; 43 \%)$, as well as in specialized emergency/urgency or psychiatric services $(6 ; 43 \%)$.

Charts 1 and 2 show the individual synthesis of articles composing the corpus of analysis, contributing to the interpretation of results.

Figure 1 - Flowchart of sample constitution

Chart 1 - Characterization of the corpus of articles from research (according to country of origin of data, methods and objectives) that adopted as investigation object institutional actions or programs/policies to curb and/or prevent violence in the nursing work (databases: CINAHL, PubMed, Scopus, Web of Science, from 1/1/2013 to 12/31/2017)

\begin{tabular}{|c|c|c|}
\hline Article/Authors/Year/Journal & $\begin{array}{l}\text { Type of study/Sample/Location/ } \\
\text { Country/Level of evidence }\end{array}$ & Objectives \\
\hline $\begin{array}{l}\text { Article } 1 \text { (Keller et al., 2016) })^{(25) / A} \text { task force to } \\
\text { address bullying/AJN. }\end{array}$ & $\begin{array}{l}\text { Quasi-experimental research/707 } \\
\text { nurses/Academic Medical Center/ } \\
\text { USA/5 }\end{array}$ & $\begin{array}{l}\text { To assess bullying in the workplace, as experienced by nurses; } \\
\text { To describe how the nurses of an academic medical center } \\
\text { certified by Magnet }{ }^{\circledR} \text { developed and implemented a task force to } \\
\text { curb the problem (BE NICE Program). }\end{array}$ \\
\hline $\begin{array}{l}\text { Article } 2 \text { (Adams et al., 2017)(26)/Assessing the } \\
\text { effectiveness of clinical education to reduce the } \\
\text { frequency and recurrence of workplace violence/ } \\
\text { Aust J Adv Nurs. }\end{array}$ & $\begin{array}{l}\text { Case study (quantitative)/31 } \\
\text { members of the nursing team/ } \\
\text { University Hospital/Australia/6 }\end{array}$ & $\begin{array}{l}\text { To evaluate the clinical education to identify patients with high } \\
\text { risk of violence and reduce the frequency of violent incidents. }\end{array}$ \\
\hline $\begin{array}{l}\text { Article } 3 \text { (Gillespie et al., 2014)(27)/A workplace } \\
\text { violence educational program: a repeated } \\
\text { measures study/ Nurse Educ Pract. }\end{array}$ & $\begin{array}{l}\text { Quasi-experimental study/120 } \\
\text { health professionals/Emergency } \\
\text { Units/USA/5 }\end{array}$ & $\begin{array}{l}\text { To evaluate the learning outcomes of a hybrid educational } \\
\text { program (online and classroom) for the prevention of } \\
\text { violence in the workplace, tailored to the needs of the } \\
\text { emergency services employees. }\end{array}$ \\
\hline $\begin{array}{l}\text { Article } 4 \text { (Gillespie et al., 2013)(28)/Evaluation } \\
\text { of a comprehensive ED violence prevention } \\
\text { program/J Emerg Nurs. }\end{array}$ & $\begin{array}{l}\text { Research-action/ } 97 \text { health } \\
\text { professionals ( } 35 \text { nurses, nine } \\
\text { doctors and } 53 \text { other employees)/ } \\
\text { Emergency Units of three } \\
\text { hospitals/USA/6 }\end{array}$ & $\begin{array}{l}\text { To develop partnerships between academic researchers, } \\
\text { doctors and emergency service leaders to implement and } \\
\text { maintain the program of prevention of violence in the } \\
\text { workplace (VAT). } \\
\text { To create, implement and evaluate the VAT prevention } \\
\text { program. }\end{array}$ \\
\hline $\begin{array}{l}\text { Article } 5 \text { (Guay et al., 2016) })^{(29)} / \text { Evaluation of an } \\
\text { education and training program to prevent and } \\
\text { manage patients' violence in a mental health } \\
\text { setting: a pretest-posttest intervention study/ } \\
\text { Healthcare. }\end{array}$ & $\begin{array}{l}\text { Cohort study } / 89 \text { mental health } \\
\text { workers/Montreal Mental Health } \\
\text { University Institute/Canada/4 }\end{array}$ & $\begin{array}{l}\text { To assess the impact of the Omega Program of Prevention } \\
\text { of Violence at Work regarding the employee's psychological } \\
\text { suffering, confidence in confrontation and perception of } \\
\text { exposure to violence. }\end{array}$ \\
\hline $\begin{array}{l}\text { Article } 6 \text { (Gillespie et al., 2014) } \\
\text { Implementation of a comprehensive } \\
\text { intervention to reduce physical assaults and } \\
\text { threats in the emergency department/J Emerg } \\
\text { Nurs. }\end{array}$ & $\begin{array}{l}\text { Quasi-experimental study/209 } \\
\text { emergency service workers } \\
\text { (nurses, doctors, psychologists, } \\
\text { security and others)/USA/5 }\end{array}$ & $\begin{array}{l}\text { To evaluate the effectiveness of a program to reduce the } \\
\text { incidence of violence in the workplace, mainly that caused } \\
\text { by visitors and patients to emergency service workers. }\end{array}$ \\
\hline
\end{tabular}




\begin{tabular}{|c|c|c|}
\hline Article/Authors/Year/Journal & $\begin{array}{l}\text { Type of study/Sample/Location/ } \\
\text { Country/Level of evidence }\end{array}$ & Objectives \\
\hline $\begin{array}{l}\text { Article } 7 \text { (Embree et al, 2013) })^{(31)} / \text { Raising level of } \\
\text { awareness of nurse-to-nurse lateral violence in a } \\
\text { critical access hospital/Nurs Res Pract. }\end{array}$ & $\begin{array}{l}\text { Quasi-experimental research/135 } \\
\text { nurses on pre- and } 143 \text { on post- } \\
\text { intervention/nurses of various } \\
\text { health services/USA/5 }\end{array}$ & $\begin{array}{l}\text { To evaluate the educational intervention for horizontal } \\
\text { violence among nurses in the workplace and to verify how } \\
\text { much this violence is perceived by them. }\end{array}$ \\
\hline $\begin{array}{l}\text { Article } 8 \text { (Al-Ali et al., 2016)(32)/The impact of } \\
\text { training program on nurses' attitudes toward } \\
\text { workplace violence in Jordan/ Appl Nurs Res. }\end{array}$ & $\begin{array}{l}\text { Quasi-experimental/97 nurses/ } \\
\text { Military Hospital/Jordan/5. }\end{array}$ & $\begin{array}{l}\text { To assess the impact of a training program on the attitudes } \\
\text { of nurses regarding violence in the workplace, in a military } \\
\text { hospital in Jordan. }\end{array}$ \\
\hline $\begin{array}{l}\text { Article } 9 \text { (Björkdahl et al, 2013) })^{(33)} / \text { The influence } \\
\text { of staff training on the violence prevention and } \\
\text { management climate in psychiatric inpatient } \\
\text { units/J Psychiatr Ment Health Nurs. }\end{array}$ & $\begin{array}{l}\text { Quasi-experimental/85 nursing } \\
\text { professionals/Psychiatric hospital/ } \\
\text { Sweden/5. }\end{array}$ & $\begin{array}{l}\text { To evaluate the influence of an educational intervention } \\
\text { with nursing professionals, named Bergen Model (training } \\
\text { program that combines preventive approach with } \\
\text { theoretical structure and positive factors of the team: } \\
\text { appraisal of patients, emotional regulation and effective } \\
\text { structure), on the prevention and management of violence } \\
\text { in the workplace, in psychiatric wards. }\end{array}$ \\
\hline 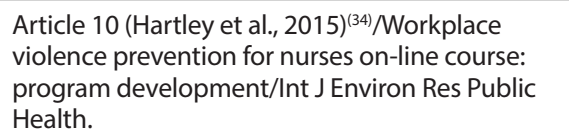 & $\begin{array}{l}\text { Qualitative research/09 nurses/ } \\
\text { USA/7. }\end{array}$ & $\begin{array}{l}\text { To describe the development, content and qualitative } \\
\text { evaluation of a free online course about the prevention of } \\
\text { violence in the workplace. }\end{array}$ \\
\hline $\begin{array}{l}\text { Article } 11 \text { (Baby et al, 2016) }{ }^{(35)} / \text { Healthcare } \\
\text { managers' perceptions of patient perpetrated } \\
\text { aggression and prevention strategies: a cross } \\
\text { sectional survey/lssues Ment Health Nurs. }\end{array}$ & $\begin{array}{l}\text { Cross-sectional research/141 } \\
\text { health managers/New Zealand/6. }\end{array}$ & $\begin{array}{l}\text { To evaluate the nature of the aggression experienced by health } \\
\text { professionals in New Zealand. To identify and asses the availability } \\
\text { and accessibility of security measures, as well as the training of } \\
\text { violence prevention and management in the workplace. }\end{array}$ \\
\hline $\begin{array}{l}\text { Article } 12 \text { (Gillespiea et al., 2015) })^{(36)} / \text { Individual, } \\
\text { relationship, workplace, and societal } \\
\text { recommendations for addressing healthcare } \\
\text { workplace violence/Work. }\end{array}$ & Theoretical study/USA/7. & $\begin{array}{l}\text { To recommend protective measures to health professionals } \\
\text { about violence in the workplace. }\end{array}$ \\
\hline $\begin{array}{l}\text { Article } 13 \text { (Gillespie et al., 2016) } \\
\text { to Stop It: A Quality Improvement Study } \\
\text { to Increase the Reporting of Workplace } \\
\text { Aggression/J Nurs Care Qual. }\end{array}$ & $\begin{array}{l}\text { Quasi-experimental research/101 } \\
\text { pre- and } 49 \text { post-intervention } \\
\text { workers of a pediatric emergency } \\
\text { service/USA/5. }\end{array}$ & $\begin{array}{l}\text { To evaluate the intervention to increase the reporting of } \\
\text { workplace aggression committed by patients and visitors. }\end{array}$ \\
\hline $\begin{array}{l}\text { Article } 14 \text { (Parker et al. 2016) } \\
\text { nurse-led culture to minimize horizontal } \\
\text { violence in the acute care setting: a multi- } \\
\text { interventional approach/J Nurses Prof Dev. }\end{array}$ & Opinion of experts/USA/7. & $\begin{array}{l}\text { To propose an educational program in line with the } \\
\text { professional profile required to prevent violent behavior and } \\
\text { to implement zero tolerance to violence. }\end{array}$ \\
\hline
\end{tabular}

Chart 2 - Main results and conclusions of articles arising from research that have adopted as object of investigation institutional actions or programs/ policies to curb and/or prevent violence in the nursing work. Databases (CINAHL, PubMed, SCOPUS, Web of Science), from 1/1/2013 to 12/31/2017

\begin{tabular}{|c|c|c|}
\hline Articles & Main results & Conclusions \\
\hline $\begin{array}{l}\text { Article 1(Keller } \\
\text { et al., 2016) }\end{array}$ & $\begin{array}{l}\text { An online learning platform called BE NICE was developed } \\
\text { to train nurses in identifying signs of bullying and to support } \\
\text { them in the confrontation, empowering them to eliminate such } \\
\text { violence in the workplace. }\end{array}$ & $\begin{array}{l}\text { Nurses in the intervention groups have reported more con- } \\
\text { fidence in managing violence and much less incivility by } \\
\text { their superiors; however, a significant decrease in horizontal } \\
\text { violence was not observed. }\end{array}$ \\
\hline $\begin{array}{l}\text { Article } 2 \\
\text { (Adams et al., } \\
\text { 2017)(26) }\end{array}$ & $\begin{array}{l}\text { The educational intervention to identify patients with a high risk } \\
\text { of violence has increased significantly the knowledge of the nurs- } \\
\text { ing team, demonstrating that the use of verbal debasement has } \\
\text { significantly increased the reduction of frequency and recurrence } \\
\text { of incidents. }\end{array}$ & $\begin{array}{l}\text { The intervention proved to be effective in the use of verbal } \\
\text { debasement and, consequently, in the reduction of inci- } \\
\text { dents; nonetheless, the need for increasing training time } \\
\text { was found. }\end{array}$ \\
\hline $\begin{array}{l}\text { Article } 3 \\
\text { (Gillespie et al., } \\
2014)^{(27)}\end{array}$ & $\begin{array}{l}\text { Evaluation six months after an educational intervention of a } \\
\text { hybrid educational program (online and classroom) for preven- } \\
\text { tion of nursing workplace violence pointed a significant increase } \\
\text { in individual learning. }\end{array}$ & $\begin{array}{l}\text { The use of a hybrid modality increased the probability of } \\
\text { achieving significant learning and retention results. }\end{array}$ \\
\hline $\begin{array}{l}\text { Article } 4 \\
\text { (Gillespie et al., }^{2013)^{(28)}}\end{array}$ & $\begin{array}{l}\text { The assessment was considered to be moderately beneficial by } \\
\text { nurses and workers and was worst evaluated by doctors. The } \\
\text { importance of the program regarding policies and procedures, } \\
\text { environmental changes, education, violence surveillance and } \\
\text { monitoring was emphasized. However, the last two items were } \\
\text { less implemented. }\end{array}$ & $\begin{array}{l}\text { The intervention allowed for implementing: risk assess- } \\
\text { ment, safe environment maintenance, risk communication, } \\
\text { response to violent events, record maintenance, surveillance } \\
\text { and monitoring. They concluded the new programs for } \\
\text { prevention and management of bullying must be created, in } \\
\text { addition to expanding the program to other services. }\end{array}$ \\
\hline $\begin{array}{l}\text { Article } 5 \text { (Guay } \\
\text { et al., 2016) }\end{array}$ & $\begin{array}{l}\text { Statistically significant improvements were seen in the short-term } \\
\text { scores and monitoring of psychic suffering, confidence in confronta- } \\
\text { tion and levels of exposure to violence. Further research is needed } \\
\text { to understand how to improve the effectiveness of the program, } \\
\text { especially among participants that are resistant to change. }\end{array}$ & $\begin{array}{l}\text { There was a positive impact of the Omega training pro- } \\
\text { gram, implemented in Canada since } 1999 . \text { Most of these } \\
\text { effects remain for more than } 14 \text { months after conclusion of } \\
\text { training. }\end{array}$ \\
\hline
\end{tabular}


Chart 2 (concluded)

\begin{tabular}{|c|c|c|}
\hline Articles & Main results & Conclusions \\
\hline $\begin{array}{l}\text { Article } 6 \\
\text { (Gillespie et al., } \\
\text { 2014)(30) }\end{array}$ & $\begin{array}{l}\text { Results do not corroborate the expected effectiveness of the } \\
\text { program to curb violence in the workplace (VAT) practiced by } \\
\text { patients and visitors against emergency service workers through } \\
\text { the perpetration of aggression. }\end{array}$ & $\begin{array}{l}\text { The failure of the program was due to the deficit of ongoing } \\
\text { commitment of leaders of these services in the notification } \\
\text { and monitoring of VAT since when there is full participation } \\
\text { of them there is a reduction. }\end{array}$ \\
\hline $\begin{array}{l}\text { Article } 7 \\
\text { (Embree et al, } \\
2013)^{(31)}\end{array}$ & $\begin{array}{l}\text { There was increase awareness on horizontal violence among } \\
\text { nurses after the educational intervention. }\end{array}$ & $\begin{array}{l}\text { Awareness on horizontal violence among nurses has } \\
\text { increased after the educational intervention; however, } \\
\text { this can be related to internal organizational changes that } \\
\text { resulted in change of function. Such awareness and en- } \\
\text { hanced skills can help improve the interpersonal relation- } \\
\text { ship, diminishing the abandonment of profession. }\end{array}$ \\
\hline $\begin{array}{l}\text { Article } 8 \text { (Al-Ali } \\
\text { et al., 2016) }\end{array}$ & $\begin{array}{l}\text { Results showed a significant impact of the training program on } \\
\text { the attitudes of nurses regarding workplace violence. }\end{array}$ & $\begin{array}{l}\text { The importance of the education of nursing professionals in } \\
\text { curbing workplace violence was verified. }\end{array}$ \\
\hline $\begin{array}{l}\text { Article } 9 \\
\text { (Björkdahl et al, } \\
\text { 2013) }\end{array}$ & $\begin{array}{l}\text { The educational intervention through the Bergen Model has } \\
\text { significantly increased the perception of violence prevention and } \\
\text { management among nursing professionals. It has positively influ- } \\
\text { enced the emotional control in challenging situations in cases of } \\
\text { patient aggression and in the team's readiness to intervene at an } \\
\text { early stage of the assault. In addition, it contributed to the good } \\
\text { relations between patients and workers, with team cooperation in } \\
\text { the vicinity of aggressive patients. }\end{array}$ & $\begin{array}{l}\text { Training combined with epidemiological approach has } \\
\text { positively influenced the prevention of violence and the } \\
\text { management climate in the perspectives of patients and } \\
\text { staff since the measures used by epidemiology brought } \\
\text { more complex evidence of the multiple causes of violence. }\end{array}$ \\
\hline $\begin{array}{l}\text { Article } 10 \\
\text { (Hartley et al., } \\
2015)^{(34)}\end{array}$ & $\begin{array}{l}\text { Online course, with } 13 \text { units of approximately } 15 \text { minutes. There } \\
\text { was approval of participants by allowing them to complete the } \\
\text { course regardless of local time. They considered the "Nurses' } \\
\text { Voices" videos as relevant illustrations of the violence nurses } \\
\text { face in their workplaces. }\end{array}$ & $\begin{array}{l}\text { The tool demonstrated effectiveness in the learning of pro- } \\
\text { fessionals for the prevention of nursing workplace violence. }\end{array}$ \\
\hline $\begin{array}{l}\text { Article } 11 \text { (Baby } \\
\text { et al, 2016) }\end{array}$ & $\begin{array}{l}\text { The study presented results of a national survey on violence in } \\
\text { health services. The etiology of violence in the perception of health } \\
\text { services managers stems from factors related to the team, patients } \\
\text { and the organization. It raise the most used security measures such } \\
\text { as the provision of security measures, including panic buttons, } \\
\text { personal alarms, use of security personnel and police. }\end{array}$ & $\begin{array}{l}\text { It is recommended to develop training programs to mini- } \\
\text { mize violence. }\end{array}$ \\
\hline $\begin{array}{l}\text { Article } 12 \\
\text { (Gillespiea et } \\
\text { al., 2015) }\end{array}$ & $\begin{array}{l}\text { Recommendations were grouped into levels: individual (to reduce } \\
\text { personal risk to health professionals); relational (to work the issue } \\
\text { of bullying among co-workers and physical violence from patients } \\
\text { and visitors); workplace (to discuss the approaches of multifaceted } \\
\text { systems for violence management). Recommendations at a society } \\
\text { level focused on a universal approach to health policy. }\end{array}$ & $\begin{array}{l}\text { The use of a model such as the socioecological one may be } \\
\text { useful in planning violence prevention efforts in the health } \\
\text { setting. }\end{array}$ \\
\hline $\begin{array}{l}\text { Article } 13 \\
\text { (Gillespie et al., } \\
\text { 2015) }\end{array}$ & $\begin{array}{l}\text { Violence notification decreased from } 53 \% \text { to } 47 \%\left(p_{=} 0,06\right) \text {. } \\
\text { Reasons for reporting were the seriousness of the incident and } \\
\text { the request for denouncement. Motives for not reporting were } \\
\text { minor incidents and the fact no action would be taken. }\end{array}$ & $\begin{array}{l}\text { The intervention was not effective. Future efforts for } \\
\text { change must consider several modes of notification, with } \\
\text { commitment of directors to promote reports. }\end{array}$ \\
\hline $\begin{array}{l}\text { Article } 14 \\
\text { (Parker et al. }_{2016)^{(38)}}\end{array}$ & $\begin{array}{l}\text { The main component for the effective culture of minimization of } \\
\text { horizontal violence in the workplace is the participation of staff } \\
\text { in the development of programs. }\end{array}$ & $\begin{array}{l}\text { The model of shared management of nursing allows for the } \\
\text { continuous discussion and incorporation of tips, adjust- } \\
\text { ments and best practices for professional development. It is } \\
\text { necessary to maintain leadership consultants until they form } \\
\text { individuals capable of handling these conflicts. }\end{array}$ \\
\hline
\end{tabular}

\section{DISCUSSION}

We verified that, in the production of knowledge on the research objects, actions and programs/policies employed to curb/prevent nursing workplace violence, specific actions prevail (57\%) over programs underlying institutional policies (43\%). Nurses were inserted as participants in all studies, whether as an isolated category (29\%), in a nursing team (43\%) or as health workers (14\%). However, these studies have been considered exclusively in international scenarios, in North American countries $(72 \%)$, mostly in the United States (65\%) and Canada (7\%), which are therefore considered world protagonists since they presented four programs.

The impact of such programs is perceived since, for instance, Canada is the country with the lowest levels of nursing workplace violence (physical violence $[\mathrm{vf}]=6.2 \%$; verbal violence $[\mathrm{vv}]=13.9 \%)^{(4)}$.
There, the Omega Program, an initiative of the Agency for Health and Safety at Work in partnership with a mental health institute specialized in violence issues, covered from 1999 to 2015 47,408 participants (health team members) nationally, demonstrating a positive impact on psychic distress, confidence in confrontation and on levels of exposure to violence ${ }^{(29)}$.

Aimed to prevent and minimize patient aggression against health professionals, the Omega training program develops specific interpersonal skills and behavioral management techniques in health professionals, so that they can intervene in situations of aggression. It uses theoretical and practical classroom strategies, focusing on the participants' experiences, divided into four days. On the first day, participants are taught the values (respect, professionalism, accountability, and security) and principles (to protect oneself, to assess the situation, to predict behavior, to take the time, and to focus on the person) of Omega; the second 
day focuses on a pacification approach, according to the classification of behaviors and levels of dangerousness; the third day deals with intervention according to the aggressor's behavior; the fourth day focuses on post-incident reports ${ }^{(29)}$.

The United States also have mobilized to reduce nursing workplace violence, allocating the largest number of programs (three); furthermore, this is one of the few countries to investigate three types of violence, exposing the highest level of sexual violence worldwide (vs) ( $v f=23.6 \%$; vv $=50.3 \%$; vs $=38.5 \%)^{(1)}$. Of the three programs carried out in the United States, two are well evaluated, namely, the BE NICE ${ }^{(25)}$ and the VAT ${ }^{(28)}$.

The fist program, called BE NICE, started from the initiative of nursing directors of a US Academic Medical Center, after recognizing bullying as a priority problem of action in the work environment in nursing. This fact led them to unite to nurses for building a institutional policy aimed at restoring a healthy work environment to the profession. The group, called Bullying Task Force, first performed a diagnosis of local violence and shared the results with the nursing team, to awaken them to the problem. Then, they developed the BE NICE Program ( $B$ = Bullying, $E$ $=$ Elimination, $\mathrm{N}=$ Nursing, $\mathrm{I}=\mathrm{In}, \mathrm{C}=$ Caring, $\mathrm{E}=$ Environment) from discussions about six interventionist programs found in the literature and local needs ${ }^{(25)}$.

After six months of the start of the program, the assessment signaled a positive impact and the institution began to consider the program to be offered annually and be part of its policy. In addition, the Bullying Task Force made itself available for playing the role of adviser/supervisor of the BE NICE defenders ${ }^{(25)}$.

It should be highlighted the goal of BE NICE is to provide participants with tools to identify signs of intimidation, support colleagues and, finally, help eliminate bullying in the workplace, without directly confronting the aggressor. The program is offered in the three work shifts of nurses, in a classroom theoreticalpractical session of three to four hours, involving discussion and simulation classes, with support of printed materials. Anti-bullying posters are distributed to participants and posted in the units so that employees are encouraged to sign them, signalizing support to the institutional initiative ${ }^{(25)}$.

The content of the program focuses on the 4S strategy: (1) Stand by: to keep the victim calm and physically aligned to your body so that they can perceive it in solidarity; (2) Support: to listen attentively, responding with empathy, acknowledging their feelings and offering encouragement to take the next steps; (3) Speak up: the defender is encouraged to speak on behalf of their colleague, reporting the psychological violence to institutional leaders. Action performed jointly with the intimidated colleague or independently of them or their interest; (4) Sequester: as a last step, the BE NICE defender must move the victim away from the situation, offering to talk with them in private. The focus here is, once again, to provide a safe and supportive environment ${ }^{(25)}$.

The second US program, called Workplace Violence Prevention Program (VAT), adopts a hybrid educational model, with online and classroom activities; however, it came from a partnership between University and emergency services. It has considered the needs of workers and services; therefore, the research-action method was used for its development: planning, implementation and evaluation. The time between project evaluation and planning was 21 months, including various strategies for determining the risk factors of emergency services through the workers' experiences with workplace violence, bibliographic survey, formation of focus groups with team leaders (doctors, nurses, nursing teacher), so that the signs of patients considered violent could be identified, as well as to define the management and strategies used after incident and to disclose all environmental risks. The process also involved meetings with safety committees of emergency departments so they could delve into the identification of risks and strategies, as well as perform policy revisions to decrease them in the workplace. Numerous meetings were needed, involving different areas (medicine, needed, security/ police, registry, management, social service and psychology) in planning the intervention ${ }^{(28)}$.

The third program, called Nurse-Nurse Horizontal Violence Prevention, has not obtained a satisfactory evaluation yet. Despite having been developed in a hospital, respecting the needs of the nursing staff, it has not presented the expected impact since the evaluation process did not point to significant changes in participants' awareness raising for this type of workplace violence. Despite the efforts undertaken through repeated invitations, in all locations of the hospital, the adherence of nurses to the program was low. Of the 135 nurses, 48 participated in pre-assessment, a number later reduced to 35 at post-assessment. The authors recommend that results should be viewed with caution due to the limitations imposed on evaluation, as the program was carried out in a single center, with low adherence, possibly affected by pressures exerted by the leadership for the nurses to participate ${ }^{(31)}$.

The fifth program raised by this research is used in Sweden since 2006, named Bergen Model. Aimed at training psychiatric health workers in violence prevention and management, it originates from the Norwegian training Terma, developed at the Haukeland University Hospital, in the Department of Forensic Psychiatry of Berburg. In Sweden, the Terma was first introduced in the psychiatric department of the Karolinska University Hospital, Huddinge, in Stockholm, where the City Model was adapted. It presents a theoretical structure based on nursing and describes the three factors considered vital for conflict reduction and restraint in psychiatric wards. Namely, (a) positive evaluation of patients: psychiatric approach that promotes a psychological understanding of the patient behavior and the moral commitment to humanistic and non-judgmental values; (b) self-regulation of emotional responses: this includes the awareness and control of emotions, mainly fear and rage; (c) effective structure of rules and routines: this includes skills of teamwork, organizational support, clarity of infirmary rules, and early recognition of feelings. Necessary interventions are arranged in the management of challenging situations for violence containment ${ }^{(33)}$.

The Bergen Model is based on good team-patient relations. Participants are encouraged to reflect on their own undeclared approach to workplace violence, as well as on the unit culture and organization. Training also includes aggression theory, ethics of caring, local rules and routines, risk factors and risk assessment laws and legislation, and the impact of physical environment. It involves definitions and limits of negotiation, self-defense, physical restraint techniques and safety issues, use of mechanical restraint, seclusion and forced medication, and 
the need for the team to perform a critical analysis after violent incidents. Furthermore, it emphasizes the essential cooperative spirit among participants and the time to try and understand the situation in depth. finding an solution acceptable to everyone involved. The program includes a four-day course for all workers in the field of psychiatry, and is into oriented theoretical and practical activities. Those responsible for the training are carefully chosen and recruited from a team that already operates in the institutional clinic and went through a preparatory course on the Berger Model. After approximately 70 hours of course, they become able to offer four-day courses, with activities offered on a regular bases in units where the workers operate, at least once every six months. Activities are based on the actual experiences of participants with patients and colleagues, and refer to both theory and practice ${ }^{(33)}$.

As one can see though this research, programs/policies employed to curb/prevent nursing workplace violence were focused on three countries: the United States, Canada and Sweden, whereas violence in nursing is a phenomenon perpetrated in working environments worldwide, regardless of being allocated in health scenarios of countries with highest development indexes or not.

Among the types of violence, verbal violence is practiced more frequently. In such incidents, Asian countries lead (Israel $=97.1 \%{ }^{(6)}$; Saudi Arabia $\left.=94.3 \%{ }^{(5)}\right)$, followed by African (Ethiopia $=89.5 \%{ }^{(9)}$ ) and European (Germany $=78.0 \%{ }^{(10)}$ ) countries.

Regarding physical violence, Germany is on top in Europe, with $63,0 \%{ }^{(10)}$, followed by China, in the Asian continent $\left(35.4 \%{ }^{(2)}\right)$, and Ethiopia, in Africa, with $18.2 \%{ }^{(9)}$. Sexual violence is little estimated, and the highest index is that of the United States $(38.5 \%)^{(1)}$, followed by Ethiopia $13.2 \%{ }^{(9)}$, Israel $11.6 \%{ }^{(6)}$ and China $(4.6 \%)^{(2)}$.

In South American countries, Brazil accounts for more than 2 million professionals, among assistants (21\%), technicians $(55 \%)$ and nurses $(24 \%)^{(20)}$; however, the movement around the violence perpetrated in nursing workplace environments is still in the process of diagnosis. Conducted and published in 2015 by Cofen, the only Brazilian study on nursing workplace violence at a national level indicated that $23.9 \%$ of nurses and $18.5 \%$ of nursing technicians and assistants have suffered some type of violence, being primarily psychological $(65.2 \% ; 67 \%)$, followed by physical $(10.6 \% ; 17.5 \%)$ and sexual $(0.6 \% ; 1 \%)$ violence ${ }^{(21)}$.

Another fact that emerged from the corpus analyzed shows that actions and programs/policies employed to curb/prevent nursing workplace violence happen in specialized urgency/ emergency or psychiatric services (43\%).
Health professionals working in these services are vulnerable to violence, so they need to be able to recognize signs that patients are becoming violent and be familiar with options to sedate agitated patients. If the sedation is not successful, physical restraint may be required. There are measures that can help minimize the likelihood of violence to health professionals, which include legislation, physical structure and increased safety ${ }^{(39)}$.

The completion of this research also allowed assessing the scarcity of studies exploring workplace violence in primary care, both in national and international scenarios. Studies in this area are still centered in the user as object of inter-family violence and in the detection of this violence by the health team ${ }^{(40-42)}$.

\section{Study limitations}

A limitation of this study was the fact this is an integrative review that, albeit using a judicious literature survey, may have laid aside some research that was outside the inclusion criteria for Portuguese, English and Spanish languages, as well as programs that were implemented, however described in other forms of publication.

\section{Contributions to the field of Nursing}

This study signals the need for undertaking efforts to spread, not only in local and national levels bu worldwide, the operationalization of programs to curb and prevent vertical and horizontal violence in nursing work environments. A phenomenon globally ravaging the health of professionals, this is often veiled or stays only as an index for situational diagnosis. Efforts are demanded from class bodies, in a more incisive movements so that programs such as those presented here can help reduce the alarming rates raised, on the basis of better working conditions and, consequently, health conditions of nursing professionals.

\section{CONCLUSIONS}

We concluded that there are effective measures to curb or prevent nursing workplace environment; however, these are still focused on three countries: the United States, Canada and Sweden. The programs, when implemented as an institutional policy, proved to be able to significantly reduce violence, and most of them is well evaluated and can serve as a model for the development and dissemination of policies, according to the needs of each location.

\section{REFERENCES}

1. Hanson GC, Perrin NA, Moss H, Laharnar N, Glass N. Workplace violence against homecare workers and its relationship with workers health outcomes: a cross-sectional study. BMC Public Health. 2015;15:11. doi: 10.1186/s12889-014-1340-7

2. Cheung T, Yip PS. Workplace violence towards nurses in Hong Kong: prevalence and correlates. BMC Public Health. 2017;17(1):196. doi: 10.1186/s12889-017-4112-3

3. Sisawo EJ, Ouédraogo SYYA, Huang SL. Workplace violence against nurses in the Gambia: mixed methods design. BMC Health Serv Res. 2017;17(1):311. doi: 10.1186/s12913-017-2258-4

4. Magnavita N. The exploding spark: workplace violence in an infectious disease hospital: a longitudinal study. Biomed Res Int. 2013;2013:316358. doi: 10.1155/2013/316358 
5. Al-Turki N, Afify AA, AlAteeq M. Violence against health workers in Family Medicine Centers. J Multidiscip Healthc. 2016;9:257-66. doi: 10.2147/JMDH.S105407

6. Shafran-Tikva S, Zelker R, Stern Z, Chinitz D. Workplace violence in a tertiary care Israeli hospital - a systematic analysis of the types of violence, the perpetrators and hospital departments. Isr J Health Policy Res. 2017;6(1):43. doi: 10.1186/s13584-017-0168-x

7. Alameddine M, Mourad Y, Dimassi H. A national study on nurses' exposure to occupational violence in Lebanon: prevalence, consequences and associated factors. PLoS One. 2015;10(9):e0137105. doi: 10.1371/journal.pone.0137105

8. Abdellah RF, Salama KM. Prevalence and risk factors of workplace violence against health care workers in emergency department in Ismailia, Egypt. Pan Afr Med J. 2017;26:21. doi: 10.11604/pamj.2017.26.21.10837

9. Fute M, Mengesha ZB, Wakgari N, Tessema GA. High prevalence of workplace violence among nurses working at public health facilities in Southern Ethiopia. BMC Nurs. 2015;14:9. doi: 10.1186/s12912-015-0062-1

10. Schablon A, Wendeler D, Kozak A, Nienhaus A, Steinke S. Prevalence and consequences of aggression and violence towards nursing and care staff in Germany: a survey. Int J Environ Res Public Health. 2018;15(6):1274. doi: 10.3390/ijerph15061274

11. Ferri P, Silvestri M, Artoni C, Di Lorenzo R. Workplace violence in different settings and among various health professionals in an Italian general hospital: a cross-sectional study. Psychol Res Behav Manag. 2016;9:263-75

12. World Health Organization-WHO. World report on violence and health [Internet]. Geneva:WHO; 2002 [Cited 2019 Apr 15]. Available from: http://www.who.int/violence_injury_prevention/violence/world_report/en/introduction.pdf

13. Velloso ISC, Araújo MT, Alves M. [Workers at a basic health unit who interface with violence]. Acta Paul Enferm [Internet]. 2011 [cited 2019 Apr 15];24(4):466-71. Available from: http://www.scielo.br/pdf/ape/v24n4/en_a04v24n4.pdf Portuguese.

14. Marinho J. Violência Ocupacional: a vítima é a enfermagem: ameaças, abusos e agressões comprometem a integridade do profissional. Coren-SP [Internet]. 2006 [cited 2019 Apr 15];66:8-13. Available from: https://portal.coren-sp.gov.br/wp-content/uploads/2018/01/66_0.pdf

15. Branco TSAP. Clima de segurança e stress entre os enfermeiros da Clínica de Santo António da Reboleira [Thesis] [Internet]. Lisboa: Universidade Lusíada; 2013 [cited 2019 Apr 15]. Available from: http://repositorio.ulusiada.pt/bitstream/11067/747/1/mgrhao_tiago_ branco_dissertacao.pdf

16. Morais-Filho LA. Violência Ocupacional contra profissionais de saúde em um hospital de urgência [Thesis] [Internet]. Natal: Universidade Federal do Rio Grande do Norte; 2009 [cited 2019 Apr 15]. Available from: https://repositorio.ufrn.br/jspui/bitstream/123456789/14685/1/ LuisAMF_DISSERT.pdf

17. Braga FS, Olschowsky, A. [Pleasure and suffering in the work of mental health nurses in the context of the psychiatric reform]. Rev Enferm UFPE. 2015;9(3):7086-94. doi: 10.5205/reuol.7505-65182-1-RV.0903201510 Portuguese.

18. Silva IV, Aquino EML, Pinto ICM. [Workplace violence in the healthcare sector: the experience of State health employees in Bahia State, Brazil]. Cad Saude Publica. 2014;30(10):2112-22. doi: 10.1590/0102-311X00146713 Portuguese.

19. Manetti, ML, Marziale, MHP, Robazzi, MLCC. [Revising psychosocial aspects of the nursing work]. Fortaleza: Rev Rene [Internet]. 2008 [Cited 2019 Apr 15];9(1):111-9. Available from: http://www.periodicos.ufc.br/rene/article/view/5010/3687 Portuguese.

20. Conselho Federal de Enfermagem (BR). Enfermagem em Números [Internet]. Brasília, DF: Cofen; 2017 [cited 2019 Apr 15]. Available from: http://www.cofen.gov.br/enfermagem-em-numeros

21. Conselho Federal de Enfermagem (BR). Pesquisa inédita traça perfil da enfermagem [Internet]. Brasília, DF: Cofen; 2015 [cited 2019 Apr 15]. Available from: http://www.cofen.gov.br/pesquisa-inedita-traca-perfil-da-enfermagem_31258.html

22. Ganong LH. Integrative reviews of nursing research. Res Nurs Health. 1987;10(1):1-11. Doi: 10.1002/nur.4770100103

23. Whittemore R, Knafl K. The integrative review: updated methodology. J Adv Nurs. 2005; 52(5):546-53. doi: 10.1111/j.1365-2648.2005.03621.x

24. Melnyk BM, Fineout-Overholt E. Evidence-based practice in nursing \& healthcare: a guide to best practice. Philadelphia: Lippincot Williams \& Wilkins; 2005. Making the case for evidence-based practice, p. 3-24.

25. Keller R, Budin WC, Allie T. A task force to address bullying. Am J Nurs. 2016;116(2):52-8. doi: 10.1097/01.NAJ.0000480497.63846.d0

26. Adams J, Knowles A, Irons G, Roddy A, Ashworth J. Assessing the effectiveness of clinical education to reduce the frequency and recurrence of workplace violence. Aust J Adv Nurs [Internet]. 2017 [cited 2017 Oct 17];34(3):6-15. Available from: http://www.ajan.com.au/Vol34/ Issue3/1Adams.pdf

27. Gillespie GL, Farra SL, Gates DM. A workplace violence educational program: a repeated measure study. Nurse Educ Pract. 2014;14(5):46872. doi: 10.1016/j.nepr.2014.04.003

28. Gillespie GL, Gates DM, Mentzel T, Al-Natour A, Kowalenko T. Evaluation of a comprehensive ED violence prevention program. J Emerg Nurs. 2013;39(4):376-83. doi: 10.1016/j.jen.2012.12.010

29. Guay S, Gonçalves J, Boyer R. Evaluation of an education and training program to prevent and manage patients' violence in a mental health setting: a pretest-posttest intervention study. Healthcare. 2016;4(3):E49. doi: 10.3390/healthcare4030049

30. Gillespie GL, Gates DM, Kowalenko T, Bresler S, Succop P. Implementation of a comprehensive intervention to reduce physical assaults and threats in the emergency department. J Emerg Nurs. 2014;40(6):586-91. doi: 10.1016/j.jen.2014.01.003

31. Embree JL, Bruner DA, White A. Raising the level of awareness of nurse-to-nurse lateral violence in a critical access hospital. Nurs Res Pract. 
2013;2013:207306. doi: 10.1155/2013/207306

32. Al-Ali, NM, Faouri, IA. The impact of training programo $n$ nurses' atitudes workplace violence in Jordan. Appl Nurs Res. 2016;30:83-9. doi: 10.1016/j.apnr.2015.11.001

33. Björkdahl A, Hansebo G, Palmstierna T. The influence of staff training on the violence prevention and management climate in psychiatric inpatient units. J Psychiatr Ment Health Nurs. 2013;20(5):396-404. doi: 10.1111/j.1365-2850.2012.01930.x

34. Hartley D, Ridenour M, Craine J, Morrill A. Workplace violence prevention for nurses on-line course: program development. Work. 2015;51(1):79-89. doi: 10.3233/WOR-141891

35. Baby M, Swain N, Gale C. Healthcare managers' perceptions of patient perpetrated aggression and prevention strategies: a cross sectional survey. Issues Ment Health Nurs. 2016;37(7):507-16. doi: 10.3109/01612840.2016.1166300

36. Gillespie LG, Gates DM, Fisher BS. Individual relationship, workplace, and societal recommendations for addressing healthcare workplace violence. Work. 2015;51(1):67-71. doi: 10.3233/WOR-141890

37. Gillespie GL, Leming-Lee TS, Crutcher T, Mattei J. Chart it to stop it: a quality improvement study to increase the reporting of workplace aggression. J Nurs Care Qual. 2016;31(3):254-61. doi: 10.1097/NCQ.0000000000000172

38. Parker KM, Harrington A, Smith CM, Sellers KF, Millenbach L. Creating a nurse-led culture to minimize horizontal violence in the acute care setting: a multi-interventional approach. J Nurses Prof Dev. 2016;32(2):56-63. doi: 10.1097/NND.0000000000000224

39. Tadros A, Kiefer C. Violence in the emergency department: a global problem. Psychiatr Clin North Am. 2017;40(3):575-84. doi: 10.1016/j. psc.2017.05.016

40. Gear C, Koziol-McLain J, Wilson D, Clark F. Developing a response to family violence in primary health care: the New Zealand experience. BMC Family Practice. 2016;17:115. doi:10.1186/s12875-016-0508-x.

41. Usta J, Taleb R. Addressing domestic violence in primary care: what the physician needs to know. Libyan J Med. 2014;9:10.3402/ljm. v9.23527. doi:10.3402/ljm.v9.23527

42. Machado JC, Rodrigues VP, Vilela ABA, Simões AV, Morais RLGL, Rocha EN. Intrafamily violence and actions strategies of the Family Health team. Saúde Soc. 2014;23(3):828-40. doi: 10.1590/S0104-12902014000300008 